\title{
STATUETTE OF ATHENE PARTHENOS.
}

THE recent discovery of a copy in marble of the chryselephantine statue of Athenè Parthenos, by Pheidias, has already led to the publication of several memoirs, ${ }^{1}$ the most recent of which by Michaelis has anticipated much that I had intended to say here. There are, however, certain points which seem to me still open to discussion. The statuette, as I have already stated in the Academy, is 1.05 metre, or rather more than 3 feet 4 inches high, inclusive of the base, and 93 centimeters without it. It represents the goddess armed with a helmet and aegis; her left hand rests on her shield set edgeways, her right hand advanced sustains a figure of Victory, her left leg is slightly bent, so that the weight of the body rests on the right leg. The goddess is clad in a talaric chiton, without sleeves, over which is an upper fold or garment falling in rich pteryges down the right side.

On her arms, bare to the shoulders, are armlets, on her neck a necklace of beads; her helmet, which fits close to the head and covers the nape of the neck, is surmounted by a tall triple crest, below which is a Sphinx flanked on either side by a winged horse. ${ }^{2} \quad$ The helmet has cheek-pieces, paragnathides,

1 Michaelis, Eine neue Copie der Parthenos des Phidias; Kabbadias,

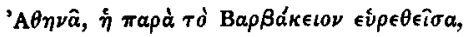
Athens, 1881 ; A. Haurette-Besnault, Statue d'Athené in Bulletin de Correspondance Hellénique, Jan. 1881, pp. 54-63; Lange in Mittheil. d. deutseh. Inst. in Athen, 1880, pp. 370-79; also

H. S.- VOL. II. my remarks, Academy, Feb. 12, 1881.

2 Hauvette-Besnault, following Pausanias, calls these Gryphons, but Lange says positively that they are winged horses, and this is confirmed by the evidence of the silver tetradrachms of Heraklea, probably of Ionia. 
turned back on hinges. A Gorgon's head ornaments the centre of the aegis and also the centre of the shield. Within the concave of the shield the serpent which Pausanias supposed to be Erichthonios is coiled; the Nikè, who holds out some object in both hands, is half turned towards the goddess. ${ }^{1}$

The statuette is of Pentelic marble, and on its discovery shewed here and there traces of gilding. The right arm is supported by a pillar, the base on which the figure stands is plain.

On comparing the statuette with the description in Pausanias and in Pliny ${ }^{2}$ we see a very satisfactory coincidence in most of the details. But the following features in the original design are wanting: the spear in the left hand of the goddess; the battle of Greeks and Amazons on the outside, and the Gigantomachia on the inside of her shield; the relief on the base representing the Birth of Pandora; the battles of Lapiths and Centaurs on the soles of the sandals.

I have already pointed out in the Academy that several of these missing details may be supplied by comparing the rude little marble figure, discovered at Athens by Charles Lenormant many years ago, with the fragment of shield formerly belonging to Lord Strangford, and now in the British Museum. On the base of the Lenormant statuette, the Birth of Pandora is indicated by a series of rudely executed figures, and on the outside of the Strangford shield the Amazonomachia is very clearly represented. For the spear in the left hand of Athenè we must look to the smaller representations of the chryselephantine statue on Athenian coins and reliefs (see Michaelis, Parthenon, Pl. XV.).

The column below the right hand of the goddess, which we find associated with the newly-discovered statue, is an unwelcome addition to the composition which I feel very reluctant to recognize as a feature in the original design of Pheidias; such an adjunct seems a very clumsy expedient and unworthy of his genius. It is true that such a support to the arm of the goddess is found on an Athenian relief published by Bötticher (see

1 According to M. Hauvette-Besnault it is probable that the object held in the hands of the Victory was a sort of wreath. Michaelis (Parthenon, p. 275 , and p. 358 of his recent $\mathrm{Me}$ moir) regards it as certainly a sash; but see Köhler, in the Mittheilungen d. deutsch. Arch. Inst. in Athen, 1880, pp. 95-96.

2 See these passages, Michaelis, Parthenon, pp. 266-270; and Overbeck, Schriftquellen. 


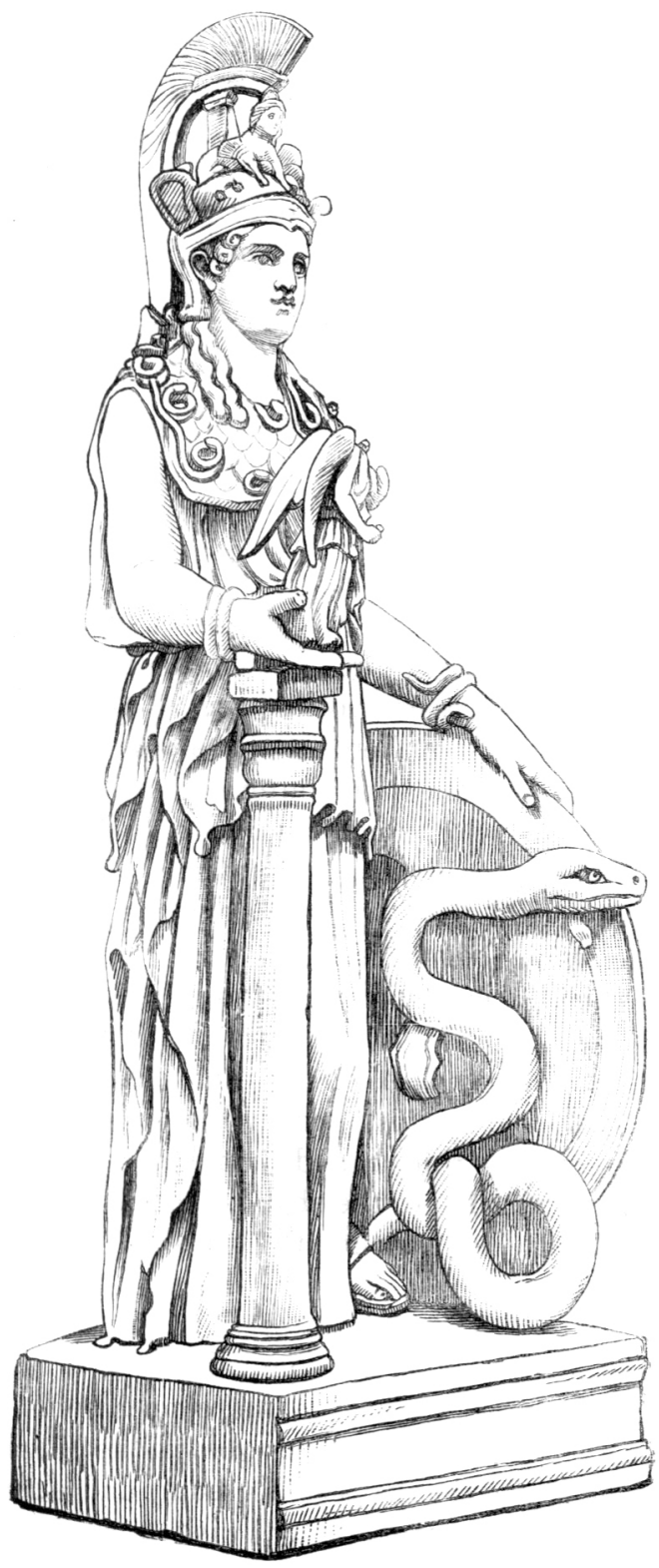

B 2 
Michaelis, Pl. xv., fig. 7), but on the other reliefs, and on coins which represent the Athene Parthenos, the arm is left free in mid-air.

Michaelis, in his recent memoir, argues that such a support may have been necessary on account of the great weight of the Victory, which is calculated to have been 4 cubits, or about 6 feet high, and which he assumes to have been, like the goddess, of gold and ivory. But I am not aware that any ancient author tells us of what material the Victory was formed, and in the absence of any evidence to the contrary I think we are justified in assuming that this figure was cast either in gold, or in some other metal gilt. This material would, I conceive, be much lighter than chryselephantine work with its inner core of wood.

Michaelis says, the weight to be sustained would have required a structure in iron such as would now be used. But why should not the ancients, who were most skilful metallurgists, have had within the chryselephantine arm of the goddess a bar of copper or wrought iron, bent at the elbow, and affording a support quite independent of the outer casing of wood on which the ivory was attached? Such a bar would be what in the language of modern architecture is called a cantilever, and its upper extremity could have been securely attached to the inner frame or skeleton of the statue.

The position of the left hand resting on the shield corresponds with that of the Lenormant statuette, and if the action of the fingers is faithfully rendered, it is not clear how the spear could have been held in this hand. It may be that the spear was held between the thumb and first finger, while the other fingers rested on the edge of the shield. This would be more in accordance with the statement of Ampelius (Lib. Mem. 8, 5) in describing the original, cujus ad sinistram clipeus appositus quem digito tangit. He also states that the spear was made of reed, de gramine. This was probably gilt. On the late silver tetradrachms of Athens, on the copper coins of Amisus in Pontus, on the celebrated Aspasios gem in the Vienna cabinet, and on other gems in the British Museum, and elsewhere, the front of the helmet is ornamented with a row of projecting horses' heads. Of these there is no trace in the newly-discovered statuette, and Michaelis (Parthenon, p. 272) appears to reject 
this ornament as if it interfered with the simplicity of the original design. Yet it is difficult to believe that it was not part of the decoration of the helmet at the date when the coins on which it appears were struck, and we have no evidence that any later addition was made to the design of Pheidias.

From p. 8 of the memoir by Mr. Kabbadias, already referred to, it appears that the Pentelic marble of this statuette was highly polished in the nude parts of the figure. This treatment is characteristic of the period of the Antonines to which I should be disposed to refer this copy, if it is not even later. ${ }^{1}$ Mr. Kabbadias further notes the following traces of colour: the eyelids of the goddess and the white of her eyes have been painted red, the circle of the iris marked by a red line, the pupil blue. The hair he describes as falling down the back in a thick club of tresses symmetrically arranged after the archaic manner. Traces of yellow colour are visible on the tresses falling over the aegis. The same colour is visible on the little curls on the temples. The eyebrows of the Gorgon's head on the aegis are painted red, the sphinx on the helmet has traces of yellow colour in the hair, and of red and blue in the eyes; the crest is red; the serpent has traces of yellow all over its body, the Gorgon's head on the shield has traces of red about the wings and serpents.

The manifest incapacity of the Roman sculptor to transmit in his mechanical copy the essential qualities of the original masterpiece, makes it very difficult to recognize any trace of the style of Pheidias in the newly-discovered statuette; in which the original breadth and simplicity of treatment have degenerated into. ignoble baldness and emptiness, and the majestic calm of the countenance has been translated into a wooden and meaningless mask.

We have, however, gained much from this discovery, which tells us not only the general features of the design, but enables us to judge more exactly what were the relative proportions of gold and ivory surfaces in the figure of the goddess. It is interesting to note how nearly the restoration given by Flaxman in his lectures on sculpture approximates to the truth. The correspondence between the height of the statuette with its

1 See the bust of Antoninus Pius, found at Cyrene, in the British Museum.

Guide to Graeco-Roman Sculptures, No. 24. 
base, 39 inches, with the 12 metres $=39$ feet, which Michaelis (Parthenon, p. 272) calculates to have been the probable height of the original, inclusive of its base, suggests the idea, that the Roman copy was reduced on the scale of an inch to a foot. I throw out this suggestion for further examination, observing obiter, that Michaelis in his recent memoir, p. 356, thinks that the proportion of height which the base in the Lenormant statuette bears to the figure, viz., a sixth, is more likely to be right than in the newly-discovered copy. It will be interesting if further exploration of the site where this statuette was found, should confirm the suggestion that in the Roman period a private house stood here, and that the newly-discovered statuette had been dedicated in a sacrarium (see Schömann, Griechische Alterthümer, ii. pp. 525-6). ${ }^{1}$

\section{T. NewTon.}

${ }^{1}$ Since this paper was printed I have seen, in the Museum at Turin, a bronze figure of Athenè about two feet high, which corresponds in attire, in general pose, and in the action of both hands, with the statnette here described. The shield, spear, and Victory are wanting, but these, being of bronze, may have perished. This figure was found in Piedmont. 